\title{
Review on Applications of Stem Cells in Veterinary Therapeutic Practices
}

\author{
Teshita Edaso, Abriham Kebede* \\ School of Veterinary Medicine, College of Medical and Health Science, Wollega University, P.O. Box, 395, \\ Nekemte, Ethiopia.
}

*Corresponding Author: Abriham Kebede, School of Veterinary Medicine, College of Medical and Health Science, Wollega University, P.O. Box, 395, Nekemte, Ethiopia. Email: abrahamkebede2016@gmail.com

\begin{abstract}
Stem cells (SCs) are the non differentiated cells but, can differentiate into other cell types to carry out different functions. These abilities to differentiate to different cell types utilized in therapeutic application of stem cells in veterinary medicine. There are four main sources of SCs, namely: embryos, fetus, umbilical cord and adult body cell. Stem cell again classified based on their ability to differentiate into: totipotent, multipotent, pluripotent and unipotent. Multipotent ASCs have advantages over ESCs like easy to get and expansion from numerous sources, less immunogenicity and no risk of teratoma formation hence used in therapeutics. SCs have been utilized for treatment of different problem like bone defects, spinal injuries, tendonitis, cartilage defects, ligament defects, wounds, cardiac defect and diabetic mellitus disease in animals. But clinical uses of stem cells are limited because of their dynamic complexity, biology, the risk of teratoma formation and the histo incompatibility. Therapeutic use of stem cells in veterinary practice is less expanded widely, even though many degenerative disorders are challenging due to their unresponsiveness to available drugs. Therefore, the objective of this manuscript is to review the therapeutic use of stem cells in regeneration of so many challenging disorders which are not responding to other means of treatment. However, the full potential of stem cells for treatment is not well known and utilized well. Therefore, the research should be continued in this area to understand more about SCs for extensive use and there should be awareness creation concerning SC based therapies in especially in Ethiopia since there is no any report found for this best treatment type for many diseases and disorders.
\end{abstract}

Keywords: Stem cells, Stem cell therapy, Veterinary medicine

List of Abbreviations

ASC: Adult Stem Cell, BM-MSC: Bone Marrow Derived Mesenchymal Stem Cell, CBESC: Cord Blood Embryonic likes Stem Cell, ESC: Embryonic Stem Cell, GM-CSF: Granulocyte-Macrophage Colony Stimulating Factor, ICM: Inner Cell Mass, MSC: Mesenchymal Stem Cell, SC: Stem Cell, SCI: Spinal Cord Injury, ISCR: International Society of Stem Cell Research, EG: Embryonic Germ, PGC: Primordial Germ Cells, iPSCs: Induced pluripotent stem cells

\section{INTRODUCTION}

Biotechnology is a key technology in the generation of an adequate food supply for the ever growing human population. The main objectives of using this biotechnology in dairy cattle are to increase production, reproductive efficiency and rates of genetic improvement. To achieve this goal, reproductive biotechnologies like: - artificial insemination (AI), synchronization, Embryo transfer (ET), in-vitro fertilization (IVF) cloning, and newly emerging biotechnologies like stem cell therapy. It can prevent venereal transmission of sexually transmitted diseases; increases milk production and also reproduce disease resistant offspring (Shibiru et al., 2017).

ARC Journal of Animal and Veterinary Sciences
Stem cells are the cells that have the ability to differentiate into different mature cells like hepatocytes, myocytes, neurons and others. In early embryos all cells are totipotent stem cells, as they have the ability to form all tissues of the organism. There are also stem cells in adult tissues that contribute to the renewal and regeneration of specific tissues (Ali et al., 2016). It used to repair system for the body, these cells in most multicellular organisms. It has capability to maintain and multiply meiotically and differentiates into a diverse range of specialized cells types (Munoz et al., 2009).

Historically, SC research began in 1981 with the milestone publication report the establishment of murine ESC. Initial use of stem cells into Page $\mid 20$ 
veterinary SCs therapy began in 1995 with injections of unprocessed bone marrow into equine suspensory ligaments. Purifying activities have been reported in the processing of fresh adipose SCs and expansion of SCs (either from bone marrow or adipose) through culture (Julie, 2013). In the last 20 years, considerable attention has been given to the research about the biology of SCs. Hence, there was a significant increase in the understanding of its characteristics and therapeutic potential for its application in different areas (Lane et al., 2014; CollartDutilleul et al., 2015).

It offers an unprecedented hope in to become some or all of more than 200 different cell types treating many degenerating diseases of humans and animals (Zwaka and Thomson, 2003). Almost all animal tissues may be repaired or regenerated by the direct action of SC (Da Silva Meirelles et al., 2006), which presents a high potential for multiplication and differentiation (Snippert and Clevers, 2011). Stem cells are undoubtedly, most promising for cell-based therapies that are currently tested in pre-clinical trials for a wide range of ailments for their therapeutic potential (Ribitsch et al., 2010; Spencer et al., 2011).

The previous studies in Veterinary sciences mostly focused on establishing procedures for isolation and their characterization of stem cell, but with advancement in array of techniques for invitro studies, stem cells rapidly became a viable tool for regenerative therapy. The multi-potential capability of stem cells can be better utilized to overcome the challenges faced by the clinicians (Gade et al., 2012b).

The applications stem cell as therapeutic potential in veterinary practice is less extensive or not widely used, even though many degenerative disorders are challenging due to their unresponsiveness to available drugs.

Therefore the objectives of this review are:

- To review potential of stem cells in regeneration of so many challenging disorders like spinal cord disease, cartilage defect, cardiac diseases, Diabet mellitus, etc those are unresponsive to other means of treatments.

- To review challenges or limitation and future perspective of stem cell therapeutic use in veterinary medicine.

\section{Potential of Stem Cells in VETERINARY REGENERATIVE THERAPIES}

Today, several veterinary diseases may be treated with the administration of SC. This is possible because these cells have a high therapeutic potential and may be injected as autologous or allogenic, freshly isolated, or previously cultured. The process is safe and brings considerable benefits to animal health. Knowledge about how ASC modulate the molecular signals to activate cell homing has also been increasingly determined through evidencing the mechanisms which enable cells to repair and regenerate injured tissues (Melissa, 2016). SCs have unique ability to differentiate into new tissues; they have been focused in the medical world. These unique qualities of SC make them ideal for treating injury and disease by repairing or replacing damaged or diseased body cells with healthy new cells (MedIndia, 2006).

\subsection{Sources of Stem Cells}

Stem cells are categorized into four types based on their sources. These classifications contain SCs from embryos, SCs from fetus, SCs from the umbilical cord and SCs from the adult (Lodi et al., 2011).

\subsubsection{Embryonic stem cells}

Embryonic stem cells are obtained from the inner cell mass (ICM) of blastocyst during embryonic development, the ICM develops into two distinct layers; the epiblast and the hypoblast. The hypoblast forms the yolk sac and the epiblast differentiates into three primordial germ layers (ectoderm, mesoderm and endoderm). ESCs present two distinctive properties: they are able to differentiate into all derivatives of three primary germ layers (pluripotency), and they are capable of propagating themselves indefinitely under defined conditions (Odorico, et al., 2001). Embryonic germ cells originate from the primordial germ cells of the gonadal ridge and are pluripotent.

They are derived from the cells of the ICM of the blastocyst during embryonic development. Once the cells are extracted from the ICM, they can be grown into ESC lines (ISCR, 2009). ESCs have the capacity to differentiate into any cell type and the ability to self-replicate for numerous generations. ESCs are in theory, able to transform into any type of tissue; they are totipotent when an egg is fertilized; then after several divisions 
are pluripotent (Rios et al., 2007). Potential disadvantages of ESCs are their ability to differentiate into different cell lineage and to proliferate endlessly unless controlled. Clinically observed teratoma which is tumor due to ESCs grows in to different and undesired tissues. ESCs can be obtained by embryo cell destruction and therefore are associated with ethical issues (Ryu et al., 2004).

\subsubsection{Fetal stem cells}

Fetal SCs are undifferentiated cell types found in the organs of fetuses. These SCs are capable to differentiate into two types: pluripotent SCs and hematopoietic SCs. Fetal blood, placenta and umbilical cord are rich sources of fetal hematopoietic stem cells (Odorico, et al., 2001). The tissue rejection due to fetal cells application can decrease the usefulness of fetal SCs (Hui et al., 2011).

\subsubsection{Stem cells from umbilical cord}

Umbilical cord contains circulating SCs. The cellular contents of umbilical cord blood appear to be quite distinct from those of bone marrows and adult peripheral blood (Rogers and Casper, 2004). The frequency of umbilical cord blood hematopoietic SCs equals or exceeds that of bone marrow and they are known to produce large amount of blood cell colonies invitro. They have long telomeres and can be expanded in long term culture (Hui et al., 2011).

Umbilical cord and cord blood-derived SCs remain the world's largest potential source of SC (Kita et al., 2010). The umbilical cord represents a well known source of endothelial progenitor cells or stem cells. It contains haematopoietic as well as non-haematopoietic SC, the latter also named as cord blood embryonic like stem cells (CBESCs) (McGuckin et al., 2003). They have been shown to differentiate into neural, hepatobiliary, pancreatic like precursors and potentially others (McGuckin et al., 2006).

\subsubsection{Adult stem cells}

Adult stem cells are any SC obtained from mature tissues. Most ASCs are lineage-restricted (multipotent) and are predominantly referred to by their tissue origin (endothelial SC, MSC, adipose-derived SCs) (Gimble et al., 2007).
Adult stem cells are of various types, hemopoeitic stem cells, mesenchymal stem cells, neural stem cells, skin stem cells, retinal stem cells etc (Wagers and Weissman, 2004). They are found in low abundance in almost all adult tissues and in high abundance in the umbilical cord (Leeb et al., 2010). ASCs are found in special regulatory niches as self renewing progenitor cells that are able to produce one or more specialized cell types. ASCs are usually considered to be tissue specific and self renewing populations of cells which can differentiate into cell types associated with the organ system in which they reside (Gomillion and Burg, 2006).

From many adult tissues of the body there are a particular type of cell specific to each tissue type with the ability to replace cells in that tissue that have died or that can heal tissue after an injury. These cells are called ASCs, which inhabit many areas of the body ranging from skin to muscle and to bone marrow. ASC is either multipotent or unipotent, so they can only differentiate into a limited number of mature cell types; usually the one tissue is which these SCs reside. Although, often very difficult to isolate due to their rarity (ISCR, 2009). ASCs play essential roles on local tissue repair and regeneration. Their therapeutic application is not as controversial as ESCs, because the production of ASC does not require the destruction of embryo. ASCs include: hematopoietic SC, MSCs, hepatic SCs, pancreatic SCs, intestinal SCs, epidermal SCs, bone and cartilage SCs, neural SCs, eye SC and others (Hui et al., 2011).

\subsubsection{Induced pluripotent stem cells (iPSCs)}

Induced pluripotent stem cells (iPSCs) are obtained by in vitro transformation of cultured adult somatic cells with genes encoding transcription factors crucial for the development of embryonic stem cells (Oct-4, Klf4, Nanog, cmyc) (Ratajczak and Suszyńska, 2013). The resultant iPSCs possessed the immortal growth characteristics of self-renewing ESCs. For example induced pluripotent stem cells were injected into mouse blastocyst and they contributed to a variety of diverse cell types, demonstrating their developmental potential (Takahashi and Yamanaka, 2006). 


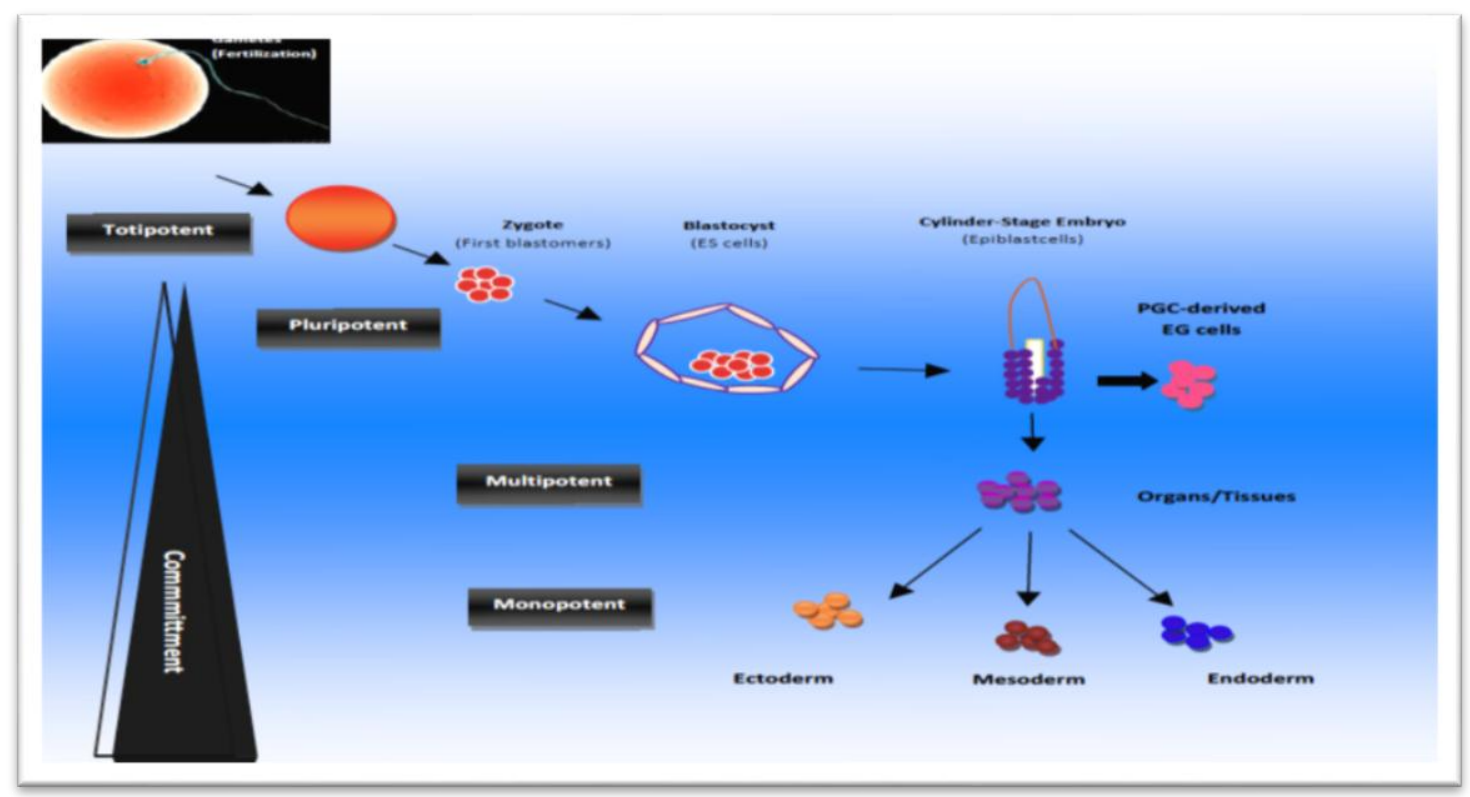

Figure1. Developmental hierarchy in stem cell compartment (Ratajczak et al., 2008).

\subsection{Types of Stem Cells}

Stem cells have several characteristics that make them unique in comparison with other mammalian cells. SCs definition includes three main criteria (Verfaillie, 2009). Ability to selfrenew for several cell divisions, which is a prerequisite for sustaining the SC pool, ability to generate at the single cell level differentiated progeny cells, in general of multiple lineages and ability to functionally reconstitute a given tissue invivo. When unspecialized SC diff erentiates, it assumes characteristics of a specific tissue (Verfaillie, 2002).

\subsubsection{Based on Potency}

Potency refers to which cell types of a given SC can differentiate into types and number of body cells. The higher the potency, the greater number of tissues the cell can form. Based on their potency, SCs can be classified into five different types (Schöler, 2007).

Totipotent stem cells: they have the ability to form all cells of an adult organism plus extraembryonic tissues such as the placenta. Only the newly fertilized zygotes through cells of the 8cell stage are considered to be totipotent; i.e. cells through about 3 days post-fertilization (Boiani and Scholer, 2005).

Pluripotent stem cells: These cells can form all cells in the adult, but cannot form placenta. Embryonic stem cells found in a day-5 blastocyst are pluripotent (Schöler, 2007).

Multipotent stem cells: The cells that have the potential to make several different cell types of related cells. Examples of multipotent cells include MSCs which have the ability to differentiate into many different tissue types and hematopoietic SCs that can form all the cellular components of blood (Ratajczak and Suszyńska, 2013).

Oligopotent stem cells: Stem cells that have the ability to form two or more cell lineages in a tissue, e.g. neuronal stem cells with ability to form different neurons types (Bajada et al., 2008).

Unipotent stem cells: The prefix "uni-" suggests, this cell type has only the ability to differentiate into one type of cell, typically the tissue from which the SC was derived. An example of this can be epithelial stem cells which appear to only be capable of making epithelial cells (Yao et al., 2012).

\subsection{Comparative Uses Types of Stem Cell}

Table1. Comparison of types of stem cells based on their advantages and disadvantages

\begin{tabular}{|l|l|l|}
\hline Types of stem cell & Advantages & Disadvantages \\
\hline Embryonic stem cell & Pluripotent stem cells have inherent capacity of & Their use is associated with ethical \\
& differentiation to cells of the three somatic germ & issues in humans as it involves \\
layers (ectoderm, endoderm and mesoderm). & destroying embryos to obtain the \\
& $\begin{array}{l}\text { ESCs may be derived from morulae } \\
\text { cells, and possibility of teratoma }\end{array}$ \\
\hline
\end{tabular}




\begin{tabular}{|c|c|c|}
\hline & $\begin{array}{l}\text { Embryonic stem cells are best from this } \\
\text { perspective due to their indefinitive replicative } \\
\text { life span attributed to their telomerase } \\
\text { expression }\end{array}$ & $\begin{array}{l}\text { formation in animals(Amarpal et } \\
\text { al., 2013) }\end{array}$ \\
\hline Fetal stem cell & $\begin{array}{l}\text { It is one of the best sources of stem cell for } \\
\text { veterinary medicine. It can be harvested without } \\
\text { any difficulty because of all fetal cell composed } \\
\text { of stem cell (Guest et al., 2010). }\end{array}$ & $\begin{array}{l}\text { It has ethical consideration due to } \\
\text { related with life killing and } \\
\text { possibility of teratoma formation } \\
\text { in animals (Guest et al., 2010). }\end{array}$ \\
\hline $\begin{array}{l}\text { Umblicalcord stem } \\
\text { cell }\end{array}$ & $\begin{array}{l}\text { They can be obtained from umbilical cord after } \\
\text { birth and can able give rise three embryonic } \\
\text { germ line in the presence of inducers (Emadedin } \\
\text { et al.,2012) }\end{array}$ & $\begin{array}{l}\text { The main disadvantage of cord } \\
\text { blood is that the volume collected } \\
\text { is fixed and relatively small. } \\
\text { Therefore, the number of stem } \\
\text { cells available for transplantation } \\
\text { is low compared to the number of } \\
\text { cells that can be collected in } \\
\text { customizable bone marrow or } \\
\text { peripheral blood stem cell harvests } \\
\text { (Lisa et al., 2016)). }\end{array}$ \\
\hline Adult stem cell & $\begin{array}{l}\text { Easy to get and it has no risk teratoma due to } \\
\text { controlled differentiation not related with } \\
\text { ethical concern by killing life and This makes } \\
\text { these cells as the most commonly used stem } \\
\text { cells (Gade et al., 2012). }\end{array}$ & $\begin{array}{l}\text { The way by which niche is able to } \\
\text { orchestrate stem cells to } \\
\text { understand and respond to signals } \\
\text { is quite challenging from the point } \\
\text { of view of molecular mechanisms, } \\
\text { development, and aging (Brien and } \\
\text { Bilder, 2013) }\end{array}$ \\
\hline Induced stem cell & $\begin{array}{l}\text { Induced pluripotent stem (iPS) cells are defined } \\
\text { as differentiated cells that have been } \\
\text { experimentally reprogrammed to pluripotent } \\
\text { cells, to achieve an embryonic stem cell like } \\
\text { State (Kumar et al., 2015). }\end{array}$ & $\begin{array}{l}\text { They lose their speciality and act as } \\
\text { embryonic stem cell possibility of } \\
\text { teratoma formation in } \\
\text { animals(Gulotta et al., 2011) }\end{array}$ \\
\hline
\end{tabular}

\subsection{Clinical Application of Stem Cells}

The general principle of SC therapy is to utilize the natural ability of the animal and human body to heal tissues through the process of regeneration. SCs are ideal candidates for use in regenerative medicine, tissue engineering, gene therapy, cell replacement therapies and cancer therapeutics. It may be possible to use SC therapies to combat major diseases such as heart disease, bone or connective tissue disorders, neural defects and hematological disorders (Korbling and Estrov, 2003).

\subsubsection{Bone Regeneration}

The mesenchyma stem cells can undergo osteogenic differentiation and exploration of the potential for using autologous SC therapy to increase bone repair and regeneration is well reported (Amarpal, 2008; Gade et al., 2012a; Udehiya et al., 2013). MSCs stimulate new bone formation in areas of implant site, indicating that either these cells were infiltrating the adjacent host bone or stimulating the host bone to regenerate new bone (Kraus and Kirker, 2006). MSCs are the most commonly used as seed cells for bone repair, because of their potential expansion of invitro and osteogenic differentiation (Barry and Murphy, 2004; Chao et al., 2007).

Bone marrow derived SCs were injected at the site of a non-union in a non-healing fracture of the humerus bone in dog. One month later, the animals showed good bony union without the signs of lameness by Ryan et al. (2005). Ease of availability and capability of allogenic bone marrow derived mesenchymal stem cell (BMMSCs) to avoid immune rejection have made these cells an attractive alternative to autogenic bone marrow-derived cells for reconstructive surgery (Arinzeh et al., 2003).

\subsubsection{Spinal Cord Regeneration}

Acute spinal injuries are common in canines and felines that lead to loss of tissue, including myelinated fibre tracts that responsible for carrying nerve impulses. The nervous tissue has limited regeneration capacity and complete restoration of locomotor activity is a challenge to modern therapeutics. The MSCs were found to have the ability to differentiate into oligodendrocytes and other cell types needed to restore neuronal function in injured spinal cord (Dobkin et al., 2006; Harris, 2008). Pluripotent cells have the ability to differentiate into neural 
tissue including neurons, astrocytes and oligodendrocytes. The presence of endogenous $\mathrm{SC}$ in the mammalian spinal cord suggests an inherent capacity for regeneration (Bambakidis et al., 2005).

Animal models showed axonal regeneration and functional recovery after spinal cord injury. Spinal cord injury is associated with a loss of neurons and glial cells, inflammation and demyelination (degeneration of the myelin sheath of a neuron), resulting in the loss of movement and sensation below the level of the lesion (Koch et al., 2009; Tewarie et al., 2009). Mesenchymal stem cells can remyelinate spinal cord axons after direct injection into the lesion (Akiyama et al., 2002).

Traumatic spinal cord injury (SCI) can lead to severe neurological damage. Even though endogenous SCs are present, recovery from this injury is difficult. A strategy to increase axonal regeneration could involve transplantation of SCs into the injured spinal cord. Five patients with acute SCI, these were treated by bone marrow derived cells and granulocytemacrophage colony stimulating factor (GMCSF). GM-CSF is a signaling molecule that induces proliferation and differentiation of bone marrow cells. Also, it possibly leads to proliferation of endogenous neural stem cells, inhibits apoptosis and activates macrophages which remove the myelin debris inhibiting regeneration. The patients showed sensory and motor function improvements with no complications (Park et al., 2005).

Neural cell SC therapy has raised the hopes in order to treat neurodegenerative diseases; which is not responsive to other treatments. In order to properly integrate in the brain cell that is injured, isolation as well as enrichment and propagation of neural SCs are necessary. Use of compliant conditions of culture and differentiation of both embryonic as well as somatic SCs in a directional manner, the clinical application of such therapies is possible nowadays (Kim and De Vellis, 2009).

\subsubsection{Tendon regeneration}

Tendon naturally heals (repairs) well, but the scar tissue formed in this repair is functionally deficient in comparison to normal tendon; this has important consequences for the animal in terms of reduced performance and a substantial risk of re-injury (Dowling, 2000). Due to the lack of effective treatments available for tendon related injuries; researchers have started to investigate the therapeutic potential of MSC for tendon repair. Recently, there has been particular interest in utilizing MSC therapy for tendon repair of race horses. Preliminary studies have described beneficial results following administration of undifferentiated autologous MSC, with functional recovery reported in nearly $90 \%$ of the horses with partial tendon damage (Pacini et al., 2007).

Mesenchymal stem cells are characterized by their unique cell surface marker proteins like: adhesion molecule, cytokines, growth factors and their receptors, extracellular matrix molecules, and their multilineage potential. These are added value to the applications of the MSCs due to their hypoimmunogenicity from lack of the major histocompatibility complex II molecular expression (Uccelli et al., 2006). In equine, autologous of BM MSCs after invitro expansion were used and found to be effective for regeneration tendon matrix in superficial flexor tendon injury (Smith et al., 2003). The collagenase induced tendinitis in the superficial digital flexor tendon in 8 horses was treated with adipose derived nucleated cells. The treated group showed improved tendon organization as exhibited by cartilage oligomeric matrix protein expression (Nixon et al., 2008).

\subsubsection{Ligament regeneration}

Most of the time race horses are especially prone to injuries of the ligaments and full functional recovery of the horses via conventional therapies is unsatisfactory. Equine suspensory ligament injuries are challenging because healing process is slow and re injuries are common (Watanabe et al., 2002). Natural healing when continues for long periods ultimately results in scar tissue formation that reduces the flexibility and movement of joint rendering the horses useless. The mechanical properties of healing ligaments are also not comparable to those of normal tissue. The quality of the ligament healing can be improved with altered therapeutic strategies including SC therapy. Ligament healing can also be enhanced by transplantation of MSCs which are demonstrated to differentiate into fibroblast like cells in ligament injury sites (Carvalho et al., 2011).

\subsubsection{Cartilage Regeneration}

Cartilaginous injuries can arise from either traumatic injury or disease. SC therapy, utilizing culture expanded MSC has been suggested as a potential reparative treatment following successful outcomes in small and large animal models (Chang et al., 2008). Single intraarticular injection of AD-MSC has been found to be efficacious in chronic osteoarthritis of the 
coxofemoral joint in dogs. Mesenchymal stem cells play an important role in regeneration of injured joint. Similarly, MSCs play a potentially important role in regenerating injured joints (Gade et al., 2012a, 2012b).

Mesenchymal stem cells can differentiate into chondrogenic lineage (Dennis et al., 2002) and can be used to treat cartilage defects. In rabbits, repair of full thickness defects of articular cartilage was observed; after transplantation of autologous MSCs dispersed in a type I collagen gel (Yan and Yu, 2007). Similarly, in the same animal model, encouraging results were obtained, after injecting calcium phosphate and hyaluronan sponge previously loaded with autologous bone marrow derived MSCs in knees with osteochondral defects (Debari et al., 2003). In a caprine osteoarthritis model it was found that the local delivery of adult MSCs to injured joints stimulates regeneration of meniscal tissue and retards the progressive destruction (Murphy et al., 2003).

Canine MSCs seeded in type I collagen glycosaminoglycan matrices were used in dogs for repair of cartilage defects of knee joints (Xiang et al., 2006). In large animal models, like sheep MSCs used for repair of chronic osteochondral (Dattena et al., 2009; Zscharnack et al., 2010). MSC therapy provides a simple, arthroscopically applicable and clinically effective approach for cartilage repair. Injecting MSC directly into the joint and is considered as a recent development. Such treatment in dogs has resulted in greater flexibility in joints and less pain (Csaki et al., 2007).

\subsubsection{Wound Healing}

Autologous bone marrow derived nucleated stem cells have been transplanted in experimental rabbits and clinical cases to evaluate their tissue regeneration potential in full thickness wounds (Borena et al., 2009), burn wounds (Oloumi et $a l ., 2008$ ) and corneal alkali burn wounds (Ye et al., 2006). Several studies indicated that MSCs derived from the bone marrow could significantly impact wound healing in diabetic and non-diabetic animals through cell differentiation and the release of paracrine factors. Culture expanded BM- MSCs have been shown to promote the healing of diabetic wounds (Wu et al., 2010). Adult bone marrow stem cells give rise to epidermal keratinocyte, follicular epithelial cells, sebaceous gland cells and dendritic cell after their transplantation in mice (Krause et al., 2001).
Bone marrow derived mesenchymal stem cell were injected around wound and their application to the wound bed in an excisional wound model enhanced healing significantly in normal and diabetic mice as $\mathrm{Wu}$ et al.(2007). BM-MSCtreated wounds exhibited significantly faster wound closure with increased reepithelialization, cellularity and angiogenesis. In addition to differentiating into keratinocytes and forming appendage like structures, BM-MSCs in the wound enhance the proliferation of endogenous keratinocytes and increase the number of regenerating appendage like structures (Wu et al., 2007).

\subsubsection{Cardiac Repairing}

The SC therapy would minimize loss of cardiomyocytes by reducing cell death, promote the return of a stunned, hibernating myocardium to normal function, stimulate revascularization of the damaged region by enhancing angiogenesis, regenerate viable cardiomyocytes thereby preserving contractile function and reducing the opportunity for scarring (Caspi et al., 2007).

MSCs when therapeutically used they improve the function of heart after an acute myocardial infarction. This could be due to the fact that MSCs can generate various signalling molecules that are cardio-protective and can differentiate into a myocyte as well as into the lineage of the vascular system (Udehiya et al., 2013).

\subsubsection{Treatment of Diabetes Mellitus}

Type-I diabetes is caused by the reduction or the absence of the hormone insulin, while Type-II is caused by a lack of response to insulin. Insulin is produced by the $\beta$-cells of the pancreas and stimulates the uptake of glucose from the blood into cells. Without insulin the resulting high levels of glucose in the blood can cause multiple medical complications. Diabetes can be temporarily controlled by the administration of exogenous insulin, but the only potential cure is offered by pancreatic transplantation or by cell therapy. Recent advances in SC therapy understanding and technology have suggested the use of pluripotent stem cells as a source of $\beta$ cells (Mayhew and Wells, 2010).

Different research has concentrated on the process of differentiating the insulin-producing cells from stem cell progenitors like (Kroon et $a l ., 2008)$. The natural development of pancreatic human $\beta$-cells has been reproduced invitro by stimulating ESCs with transcription factors, cytokines and other small molecules to differentiate them into functional mature $\beta$-cells (Evans-Molina et al., 2009). 


\subsection{Current Clinical Applications of Stem Cell Reports}

Table2. Some reports of stem cell applications in treatment of diseases and disorders

\begin{tabular}{|c|c|c|c|}
\hline No & Types organ diseases treated by stem cell & Type of animal treated & References \\
\hline 1 & Myocardial infarction and Cardiac repairing & Dog & $\begin{array}{l}\text { Gade et al., } 2012 \text { b in } \\
\text { Kamdhenu University, } \\
\text { Gandhinagar, Gujarat, India. }\end{array}$ \\
\hline 2 & Diabetes mellitus & rhesus monkey & $\begin{array}{l}\text { Zhu et al., } 2011 \text { in } \\
\text { Laboratory of Chemical } \\
\text { Genomics, Shenzhen } \\
\text { Graduate School of Peking } \\
\text { University, Shenzhen, } \\
\text { People's Republic of China. }\end{array}$ \\
\hline 3 & Cartilage regeneration & Rabbit & $\begin{array}{l}\text { Yan and Yu, } 2007 \text { in } \\
\text { Institute of Sports Medicine, } \\
\text { Third Hospital, Peking } \\
\text { University, Beijing, China. }\end{array}$ \\
\hline 4 & Wound healing & Rabbit & $\begin{array}{l}\text { Borena et al., } 2009 \text { in Indian } \\
\text { Veterinary } \\
\text { Institute, Izatnagar } 243122 \\
\text { (UP), India }\end{array}$ \\
\hline 5 & Ligament regeneration & Horse & $\begin{array}{l}\text { Herthel, } 2001 \text { in Alamo } \\
\text { Pintado Equine Medical } \\
\text { Center, Los Olivos, CA } \\
\text { 93441. }\end{array}$ \\
\hline 6 & Leukemia & Dog & $\begin{array}{l}\text { Gomes et al } 2017 \text { in } \\
\text { Department of Veterinary } \\
\text { Medicine, Faculty of } \\
\text { Animal Science and Food } \\
\text { Engineer, University of Sao } \\
\text { Paulo, Av. Duque de Caxias } \\
\text { Norte, 225, Pirassununga, } \\
\text { SP 13635-900, Brazil. }\end{array}$ \\
\hline 7 & Tendon regeneration & Horse & $\begin{array}{l}\text { Smith et al., } 2003 \text { at } \\
\text { University College, } \\
\text { London, UK. }\end{array}$ \\
\hline 8 & Bone regeneration & Dog & $\begin{array}{l}\text { Bruder et al., } 1998 \text { at } \\
\text { Baltimore, Maryland } 21231 \text {, } \\
\text { USA }\end{array}$ \\
\hline 9 & Spinal cord regeneration & Rhesus monkey & $\begin{array}{l}\text { Deng et al., } 2006 \text { at Sun Yat- } \\
\text { Sen University, Guangzhou } \\
510089 \text {, China. }\end{array}$ \\
\hline
\end{tabular}

In Ethiopia there is no any report of therapeutic use of stem cell in veterinary medicine.

\subsection{Challenges and Limitation of Stem Cells Therapies}

There are many challenges that are necessary to explore and fasten the growth of SC therapies. As example Embryonic stem cells (ESC) have unlimited self-renewal ability and the capacity to differentiate into any specialized cell type, therefore, could represent an unlimited cell source for tissue regeneration. However, research on these cells has been hampered or banned in some countries because of the ethical concerns about destroying human embryos and animal welfare to obtain them (Cet Stem BioPharma website, 2018, American Veterinary Medical Association website, 2018). Another major limiting factor for their usefulness in clinical therapy lies in their risk of uncontrolled growth and potential danger of teratoma formation and immunological intolerance (Solter, 2006).

The use of SC in cells and tissue transplantation as therapeutic require donor and recipient tissues to be compatible. The major difficulties scientist encounter is the identification SCs from adult tissues and the process to successfully trigger differentiation in to the desired cell type is another challenge for researchers. The cost is extremely expensive (Zhili et al., 2014).

\section{Conclusion and Future Prospective OF STEM CELL THERAPY}

Stem cells are most promising for cell-based therapies, thereby provides a powerful and 
flexible option for veterinarians to restore function and improve animal health through the novel techniques. The capability of SCs to self replicate to differentiate into a specific, more specialized cell type is what makes useful in the treatment of specific disease. In veterinary sciences, SCs are mainly used for the treatment in canines and equines whereas research is still going on in other farm animals. However, their extensive use in all clinical condition cannot be exploited because of high treatment expenditure, certain chronic and irreparable conditions can be better treated with these cells and the cost of production will hopefully be reduced when extent of production is increased. Although SCs have immense potential in therapeutics, their full clinical uses requires extensive research for standardization of the treatment protocols, routes and doses. Further, guidelines and regulations for the controlled use of SCs in animals will become a near future need.

Based on the conclusion above, the following suggestions and recommendations are forwarded:

- The research should be continued on stem cells area to understand the several characteristics, molecular control and regulation in the SCs.

- The veterinarians, researchers and scientist need be aware of SC based therapies, concerning its regulations and application to ensure therapeutic use to animal.

- Other alternatives source of SC like mesenchyma stem cell should be used in ethical issues associated without destructing embryos and animal welfare affecting.

- Health sector along with government support should focus on research and clinical therapies in reasonable price in area of SCs.

- The knowledge about stem cell should be increased for better use through storing of stem cell and its dose to be used

\section{ACKNOWLEDGEMENTS}

We were like to express our gratitude to Wollega University, College of Medical and health science, School of Veterinary Medicine and the Staff of School of Veterinary Medicine for inspiration and comprehensive moral support

\section{AUTHORS' CONTRIBUTIONS}

"Abriham kebede Deresa has contributed to design the title and reviewing the manuscript to be ready for publication". "Teshita Edaso Beriso has participated in the data collection from different pdf and compiles the manuscript. All authors read and approved the final manuscript".

\section{REFERENCES}

[1] Akiyama Y., Radtke C., Honmou O. and Kocsis J. (2002). Remyelination of the spinal cord following intravenous delivery of bone marrow cells. J. A. M. Glia., 39: 229-236.

[2] Ali S., Ahmad A., Iqbal M., Muhammad A., Irfan M. and Akhter S. (2016). Opportunities for Stem Cells Therapy in Veterinary Medicine. PSM. Vet. Res., 1(2): 60-68.

[3] Amarpal, (2008). Utility of stem cells in veterinary medicine (Translated from Hindi). $J$. Kheti., 61(5): 25-26.

[4] American Veterinary Medical Association website Therapeutic use of stem cells andregenerative medicine avma.org/About/Governance/Documents/2017 S_Resolution4_attch. pdf. Accessed January 18, 2018.

[5] Arinzeh T., Peter S., Archambault M., van den Bos C., Gordon S., Kraus K et al. (2003). Allogenic mesenchymal stem cells regenerate bone in a critical-sized canine segmental defect. J. Bone and Joint Surge, Amer., 85(10): 19271935.

[6] Bajada S., Mazakova I., Ashton B., Richardson J. and Ashammakhi N. (2008). Stem Cells in Regenerative Medicine. Orthopaedic Hospital, Oswestry, Shropshire UK., 4: 4-20.

[7] Bambakidis N., Theodore N., Nakaji P., Harvey A. (2005). Endogenous stem cell proliferation after central nervous system injury: alternative therapeutic options. Eurosurg. Focus., 19.

[8] Barry F. P. and Murphy J. M. (2004). Mesench ymal stem cell: clinical application and biologic al characterization. Izvestiya Rossiiskoi Akademii Nauk. Seriya Biologicheskaya., 1: 625.

[9] Bishop A. E., Buttery L. D. and Polak J. M. (2002). Embryonic stem cells. J. Pathol., 197: 424-429.

[10] Boiani M. and Scholer H. (2005). Regulatory networks in embryo-derived pluripotent stem cells. Nat. Rev. Mol. Cell Biol., 6(11): 872-884.

[11] Borena B., Pawde A., Amarpal, Aithal H., Kinjavdekar P., Singh R et al. (2009). Autologous bone marrow-derived cells for healing excisional dermal wounds of rabbits. Vet. Record., 165(19): 563-568.

[12] Borena, B.M., Pawde, A.M., Amarpal, Aithal, H.P., Kinjavdekar, P., Singh, R. and Kumar, D. 2009. Autologous bone marrow-derived cells for healing excisional dermal wounds of rabbits. Veterinary Record, 165(19): 563-8.

[13] Brien L. E. O' and Bilder D, 2013. "Beyond the niche: tissue-level coordination of stem cell 
dynamics," Annual Review of Cell and Developmental Biology, vol. 29, pp. 107-136

[14] Bruder, S.P., Kraus, K., Goldberg, V. and Kadiyala, S. 1998. The effect of implants loaded with autologous mesenchymal stem cells on the healing of canine segmental bone defects. The Journal of Bone and Joint Surgery, Incorporated 80-A: 985-

[15] Carvalho A. M., Alves A. L., Oliveira P. G., Alvarez L. C., Amorim R. L., Hussni C. A et al. (2011). Use of adipose tissue-derived mesenchymal stem cells for experimental tendinitis therapy in equines. Equine Vet. Sc., 31(1): 26-34.

[16] Caspi O., Huber I., Kehat I., Habib M., Arbel G., Gepstein A et al. (2007). Transplantation of human embryonic stem cell derived cardiomyocytes improves myocardial performance in infarcted rat hearts. J. Ame. Colleg. Cardio., 50(19): 1884-1893.

[17] Cet Stem BioPharma website. Vet Stem Regenerative cells - key safety factors. vetstem.com/safety. php. Accessed January 19, 2018.

[18] Chang F., Ishii T., Yanai T., Mishima H., Akaogi H., Ogawa T. and Ochiai N. (2008). Repair of large full-thickness articular cartilage defects by transplantation of autologous uncultured bonemarrow- derived mononuclear cells. J. Orthop Res., 26: 18-26.

[19] Chao H., Zoghbi H. and Rosenmund C. (2007). Controls excitatory synaptic strength by regulating glutamatergic synapse number. Neuron., 56(1): 58-65.

[20] Collart-Dutilleul P., Chaubron F., De Vos J. and Cuisinier F. (2015). "Allogenic banking of dental pulp stem cells for innovative therapeutics". World. J. St. C., 7(7): 1010-1021.

[21] Csaki C., Matis U., Mobasheri A.,Ye H. and Shakibaei M. (2007). Chondrogenesis, osteogenesisand adipogenesis of canine mesenc hymal stem cells: a biochemical, morphological and ultrastructural study. Histochem and Cell Biol., 128(6): 507-520.

[22] Da Silva Meirelles L., Chagastelles P. and Nardi N. (2006) "Mesenchymal stem cells reside in virtually all post-natal organs and tissues." $J$. Cell Sc., 119(11): 2204-2213.

[23] Dattena M., Pilichi S., Rocca S., Mara L.Casu S ., Masala G. et al. (2009). Sheep embryonic ste $\mathrm{m}$ likecells transplanted in fullthickness cartilag e defects. J. Tissue Engin. And Regenerative Med., 3(3): 175-187.

[24] Debari C., Dell'Accio F., Vandenabeele F., Vermeesch J., Raymeckers J. and Luten F. (2003).

Skeletal muscle repair by adult human mesench ymal stem cell from synovial membranes. The J. of Cell Biol., 160(6): 807-809.
[25] Deng, Y.B., Liu, X.G., Liu, Z.G., Liu, X.L., Liu, Y. and Zhou, G.Q. 2006. Implantation of BM mesenchymal stem cells into injured spinal cord elicits de novo neurogenesis and functional recovery: evidence from a study in rhesus monkeys. Cytotherapy, 8: 210-214.

[26] Dennis J., Carbillet J., Caplan A. and Charbord P. (2002). The STRO. Marrow cell population is multipotential. Cells Tissue Org., 170: 73-82.

[27] Dobkin B., Curt A. and Guest J. (2006). Cellular transplants in China: observational study from the largest human experiment in chronic spinal cord injury. Neuron rehabilitation and Neural Repair., 20(1): 5-13.

[28] Dowling B. A. (2000). Superficial digital flexor tendonitis in the horse. Equine Vet. J., 32: 369378.

[29] Emadedin M, Aghdami N, Taghiyar L, Fazeli R, Moghadasali R, Jahangir S, Farjad R, Baghaban $\mathrm{E}$ (2012). Intra arthicular injection of autologus mesenchymal stem cells in six patient with knee osteoarthritis. Arch.Iran. med.15:422-428.

[30] Evans Molina C., Vestermark G. and Mirmira R. (2009). Development of insulin producing cells from primitive biologic precursors. Current Opinion in Organ Transpl., 14(1): 56.

[31] Gade N., Pratheesh M., Nath A., Dubey P. And Sharma G. (2012b). Therapeutic potential of stem cells in veterinary practice. J. Vet. World., 5(8): 499-507.

[32] Gade N., Pratheesh M., Nath A., Dubey P., Saikumar G. and Sharma G. (2012a). Stem cell therapy in animal sciences. A review. Agri. Revi., 33(2): 15-16.

[33] Gade, N.E., Pratheesh, M.D., Nath, A., Dubey, P.K., Amarpal and Sharma. G.T. 2012b. Therapeutic potential of stem cells in veterinary practice. Veterinary World, 5(8): 499-507.

[34] Gimble J. M., Katz A. J. and Bunnell B. A. (2007). Adipose derived stem cells for regenerative medicine. Circ Res., 100 (9): 12491260.

[35] Gomes I.S., Oliveira V.C., Pinheiro A.O., Roballo K.C.S., Araujo G.S.M., Veronezi, J.C., Martins D.S. \& Ambrósio C.E. 2017. Bone marrow stem cell applied in the canine veterinary clinics. Pesquisa Veterinária Brasileira 37(10):1139-1145

[36] Gomillion C. T. and Burg K. J. (2006). Stem cells and adipose tissue engineering. J. Biom., 27: 6052-6063.

[37] Gulotta V, KovacevicD, packerD, Dend H,Rodeo S (2011) Bonemarrow derived mesenchyma stem cell transduced with scelarixis improve rotator cuff healing in rat model Am. J. sports medicine 39:1282-1289.

[38] Harris D. T. (2008). Cord blood stem cells: A review of potential neurological applications. $J$. Stem Cell Rev. and Repor., 4: 269-274. 
[39] Herthel, D.J. 2001. Enhanced suspensory ligament healing in 100 horses by stem cell and other bone marrow components. Association of Equine Practitioners, 47: 319-21.

[40] Hui H., Tang Y., Hu M. and Zhao X. (2011). Stem Cell: General Feature and Characteristis. Stem Cell in Clinic and Research.

[41] International Society of Stem Cell Research (ISCR). (2009). Frequently Asked Questions on Stem Cell Research. ISSCR. http://isscr.org/ science/faq.htm.

[42] Julie R. J. (2013). New Therapy for Old Disease. Dan Niguel Veterinary Hospital Dana Point, California.

[43] Kim S. and De Vellis J. (2009). Stem cell-based cell therapy in neurological diseases: a review. J. of Neurosc. Res., 87(10): 2183-2200.

[44] Kita K., Gauglitz G., Phan T., Herndon D. and Jeschke M. (2010). Isolation and Characterization of mesenchymal stem cells from the subamnioti $\mathrm{c}$ human umbilical cord lining membrane. Stem Cells Dev., 19: 491-502.

[45] Koch P., Kokaia Z., Lindvall O. and Brüstle O. (2009). Emerging concepts in neural stem cell research: Autologous repair and cell-based disease modeling. The Lancet Neur., 8(9): 819829.

[46] Korbling M. and Estrov Z. (2003). Adult stem cells for tissue repair a new therapeutic concept. New Engl. J. Med., 349: 570.

[47] Kraus K. and Kirker C. (2006). Mesenchymal s tem cell and bone regeneration. Vet. Surge., 35: 232-242.

[48] Krause D., Theise N., Collector M., Hengariu O., Hwang S., Gardner R et al. (2001). Multi organ, multi lineage engraftment by a single bone marrow derived stem cell. J. Amer. Cell., 105: 369-377.

[49] Kroon E., Martinson L., Kadoya K., Bang A., Kelly O. and Eliazer S. (2008). Pancreatic endoderm derived from human embryonic stem cells generates glucose-responsive

[50] Kumar, D. Talluri, T. R. Anand, T.and Kues, W. A. 2015 "Induced pluripotent stemcells: mechanisms, achievements and perspectives in farm animals," World Journal of Stem Cells, vol. 7, no. 2, pp. 315-328, . insulin-secreting cells in vivo. Nat. Biotechnol., 26(4): 443-452.

[51] Lane S. W., Williams D. A. and Watt F. M. (2014). Modulating the stem cell niche for tissue regeneration. Nature Biotechnol., 32(8): 795803.

[52] Leeb C., Jurga M., McGuckin C., Moriggl R. and Kenner L. (2010). Promising new sources for pluripotent stem cells. Stem Cell Rev., 6: 1526.

[53] Lisa Peberdy, Jeanine Young, Lauren Kearney (2016). Health care professionals' knowledge, attitudes and practices relating to umbilical cord blood banking and donation: an integrative review BMC Pregnancy Childbirth. 16: 81. Published online 2016 Apr 19. doi: 10.1186/s12884-016-0863-6.

[54] Lodi D., Iannitti T. and Palmieri B. (2011). Stem cells in clinical practice: applications and warning. J. Exper. and Clinical Cancer Res., 30: 9-29.

[55] Mayhew C. N. and Wells J. M. (2010). Converting human pluripotent stem cells into beta cells: recent advances and future challenges. Current Opinion in Organ Transp., 15(1): 54 .

[56] McGuckin C., Forraz N., Baradez M., Basford C., Dickinson A., Navran S et al. (2006). Embryonic-like stem cells from umbilical cord blood and potential for neural modeling. Acta Neurobiol. Exp., 66: 321-329.

[57] McGuckin C., Pearce D., Forraz N., Tooze J., Watt S. and Pettengell R. (2003). Multiparametric analysis of immature cell populations in umbilical cord blood and bone marrow. Eur. J. Haematol., 71: 341-350.

[58] MedIndia.com (2006). Stem Cells Fundamental . Medindia Health Network Pvt. Ltd. http://ww w.medindia.net/patients/patientinfo/stemcells.ht m.

[59] Melissa M. M. (2016). Advances in the Use of Stem Cells in Veterinary Medicine.

[60] Munoz M., Trigal B., Molina I., Diez C., Cammano J. and Gomez, E. (2009). Constraints to progress in embryonic stem cells from domestic species. Stem Cell Rev. and Rep., 5: 69.

[61] Murphy J. M., Fink D. J., Hunziker E. B. and Barry F. P. (2003). Stem cell therapy in a caprine model of osteoarthritis. J. Arthritis and Rheum., 48: 3464- 3474.

[62] Nixon A. J., Dahlgren L. A., Haupt J. L., Yeager A. E. and Ward D. L. (2008). Effect of adiposederived nucleated cell fractions on tendon repair in horses with collagenase-induced tendinitis. Amer. J. Vet. Res., 69(7): 928-937.

[63] Odorico, J.S., Kaufman, D.S., and Thomson, J.A. (2001). Multilineage differentiation from human embryonic stem cell lines. Stem Cells 19:193-204.

[64] Oloumi M., Derakhshanfar A., Shemali H. and Shavalian M. (2008). The role of autogenous bone marrow in the healing of experimental burn wound healing in rabbits. Iranian J. Vet. Surge., 3(2): 47-55.

[65] Pacini S., Spinabella S., Trombi L., Fazzi R., G alimberti S., Dini F et al. (2007). Suspension of bone marrow derived undifferentiated mesench ymal stromal cells for repair of superficial digital flexor tendon in race horses. Tissue Eng., 13: 2949-2955. 
[66] Park H., Shim Y., Ha Y., Yoon S., Park S., Cho i B et al. (2005). Treatment of completes spinal cord injury patients by autologous bone marrow cell transplantation and administration of granulocyte-macrophage colony stimulating factor. Tissue Eng. May-Jun., 11(5-6): 913-922.

[67] Ratajczak M. and Suszyńska M. (2013). Quo vadis regenerative medicine. Acta Haematologica Polonica., 44: 161.

[68] Ratajczak M., Zuba-Surma E., Wysoczynski M., Wan W., Ratajczak J., Wojakowski W et al. (2008). Hunt for pluripotent stem cell Regenerative medicine search for almighty cell. J. Autoimmu., 30: 151-162.

[69] Ratajczak M. and Suszyńska M. (2013). Quo va dis regenerative medicine. Acta Haematolog. Polonica., 44: 161-170.

[70] Ribitsch I., Burk J., Delling U., Geibler C., Gittel C. and Brehm W. (2010). Basic Science and Clinical Application of Stem Cells in Veterinary Medicine. Adv. Biochem. Eng. Biotechnol., 123: 219-263.

[71] Rios C., McCarthy M., Arcierco C. (2007). Biologics in shoulder surgery: The role of adult mesenchymal stem cells in tendon repair. Tech. Orthop., 22(1): 2-9.

[72] Rogers I. and Casper R. (2004). Umbilical cord blood stem cells. In Best Practice and Research Clinical Obstetrics and Ginecology, eds: N. Fisk and J. Itskovitz, London: Elsevier Ltd.

[73] Ryan J. M., Barry F. P., Murphy J. M. and Mahon B. P. (2005). Mesenchymal stem cells avoid allogeneic rejection. J. Inflamm., 2: 8.

[74] Ryu K. H., Cho S. J., Jung Y. J., Seoh J. Y. and Kie J. H. (2004). Invitro generation of functional dendritic cells from human umbilical cord blood CD34+ cells by a 2-step culture method. Int J Hematol., 80: 281-286.

[75] Schöler H.R. (2007). The potential of stem cells: An Inventory. In Knoepffler $\mathrm{N}$ and Schip anski D (Eds.), Human biotechnology as Social Challenge. Ashgate Publishing, England, UK., Pp: 28.

[76] Shamblott M., Axelman J. and Wang S. (1998). Derivation of pluripotent stem cells from cultured human primordial germ cells. Proc Natl Acad Sci USA., 95: 13726-13731.

[77] Shibiru B, Abriham K and Ashebr A 2017. Review On Reproductive Biotechnology And Its Role In Dairy Cattle Production And Health. Rep Opinion;9(3):60-70]. ISSN 1553-9873 (print); ISSN 2375-7205 (online). http://www. sciencepub.net/report.10.doi:10.7537/marsroj 090317.10.

[78] Smith R., Korada M., Blunn G. and Godship A. (2003). Isolation and implantation of autologou $\mathrm{s}$ equine mesenchymal stem cells from bone ma rrow into superficial digital flexor tendons as a potential novel treatment. Equine Vet. J., 35(1): 99-102.

ARC Journal of Animal and Veterinary Sciences
[79] Smith, R.K.W., Korada, M., Blunn, G.W. and Goodship, A.E. 2003. Isolation and implantation of autologous equine mesenchymal stem cells from bone marrow into superficial digital flexor tendon as a potential novel treatment. Equine Veterinary Journal, 35(1): 99-102.

[80] Snippert H. and Clevers H. (2011). Tracking adult stem cells. EMBO. Repor., 12(2): 113122.

[81] Solter D. (2006). From teratocarcinomas to embryonic stem cells and beyond: a history of embryonic stem cell research. Nat. Rev. Genet., 7: 319-327.

[82] Spencer N. D., Gimble J. M. and Lopez M. J. (2011). Mesenchymal stromal cells. past, present, and future. Vet. Surg., 40(2): 129-39.

[83] Takahashi K. and Yamanaka S. (2006). Induction of Pluripotent Stem Cells from Mouse Embryonic and Adult Fibroblast Cultures by Defined Factors. Cell., 126: 663-676.

[84] Tewarie R., Hurtado A., Bartels R., Grotenhuis A. and Oudega M. (2009) Stem Cell-Based therapies for spinal cord injury. J. Spinal Cord Med., 32(2): 105.

[85] Uccelli A., Moretta L. and Pistoia V. (2006). I mmunoregulatory function of mesenchymal stem cells. Eur. J. Immunol., 36: 2566-2573.

[86] Udehiya R., Aithal H., Kinjavdekar P., Pawde A., Singh R. and Sharma G. T. (2013). Compari son of autogenic and allogenic bone marrow derived mesenchymal stem cells for repair of segmental bone defects in rabbits. Res. Vet. Sc., 94: 743-752.

[87] Vats A., Tolley N., Polak J. and Buttery L. (200 2). Stem cells: Sources and applications. Clin.O tolaryngol. Allied Sc., 27: 227-232.

[88] Verfaillie C. (2009). Pluripotent stem cells. Transf. Cliniq. Biologique., 16: 65-69.

[89] Verfaillie C.M. (2002). Adult stem cells: assessing the case for pluripotency. Trends Cell Biol., 12: 502-508.

[90] Wagers, A.J. and Weissman, I.L. (2004). Plasticity of Adult Stem Cells. Cell, 116: 639648.

[91] Watanabe N., Woo S., Papageorgiou C., Celechovsky C. and Takai S. (2002). Fate of donor bone marrow cells in medial collateral ligament after simulated autologous transplantation. Micros. Res. and Techn., 58(1): 39-44.

[92] Wu Y., Zhao R. and Tredget E. (2010). Concise review: bone marrow derived stem/pro enitor cells in cutaneous repair and regeneration. $J . S$ C., 28: 905-915.

[93] Wu Y., Chen L., Scott P. and Tredget E. (2007) . Mesenchymal stem cell enhance wound healin $\mathrm{g}$ through differentiation and angiogenesis. Amer. J. SC., 25: 2648-2659. 
[94] Xiang Z., Hu W., Kong Q., Zhou H. and Zhang X. (2006). Preliminary study of mesenchyml stem cells-seeded type I collagenglycosaminoglycan matrices for cartilage repair. Zhongguo Xiu Fu Chong Jian WaiKe ZaZhi., 20(2): 148-154.

[95] Yan H. and Yu C. (2007). Repair of fullthickness cartilage defects with cells of different origin in a rabbit model. Arthros., 23: 178-187.

[96] Yan, H. and Yu, C. 2007. Repair of fullthickness cartilage defects with cells of different origin in a rabbit model. Arthroscopy, 23: 178187.

[97] Yao J., Woon C., Behn A., Korotkova T., Park D., Gajendran V et al. (2012). The effect of suture coated with mesenchymal stem cells and bioactive substrate on tendon repaire strength on rat model. J. Hand. Surge. Am., 37: 1639-1645.

[98] Ye J., Yao K. and Kim J. (2006). Mesenchymal stem cell transplantation in a rabbit corneal alkali burn model: engraftment and involvement in wound healing. Eye Lond., 20(4): 482-90.
[99] Zhili R., Meiyan W., Zheng H., Martin S., Anand G., Yong Y et al. (2014). An effective approach to prevent immune rejection of hESC derived allograft. Cell J. SC., 14: 121-123.

[100]Zhu FF, Zhang PB, Zhang DH, Sui X, Yin M, Xiang TT, et al. Generation of pancreatic insulinproducing cells from rhesus monkey induced pluripotent stem cells. Diabetologia. 2011; 54(9): 2325-36.

[101]Zscharnack M., Hepp P., Richter R., Aigner T., Schulz R., Somerson J et al. (2010). Repair of chronic osteochondral defects using predifferentiated mesenchymal stem cells in an ovine model. Amer. J. Sport. Med., 38(9): 18571869.

[102]Zwaka T. P. and Thomson J. A. (2003). Homologous recombination in human embryonic stem cells. Nat Biotechnol., 3: 319321.

Citation: Teshita Edaso, Abriham Kebede. Review on Applications of Stem Cells in Veterinary Therapeutic Practices. ARC Journal of Animal and Veterinary Sciences. 2018; 4(2):20-32. doi: dx.doi.org/ 10.20431/24552518.0402004 .

Copyright: (C) 2018 Authors. This is an open-access article distributed under the terms of the Creative Commons Attribution License, which permits unrestricted use, distribution, and reproduction in any medium, provided the original author and source are credited. 